\section{Moderne om placenta for forskere og klinikere}

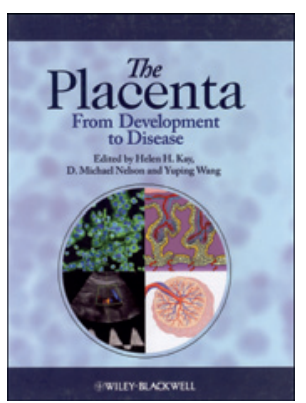

Helen H. Kay, D. Michael Nelson,

Yuping Wang, red.

\section{The placenta}

From development to disease. 346 s, tab, ill

Chichester: Wiley-Blackwell, 2011.

Pris GBP 120

ISBN 978-1-4443-3366-4

Målgruppen spenner fra nybegynnere i feltet til erfarne klinikere og forskere. Læreboken treffer målgruppene på en fortreffelig måte, og jeg anbefaler den til alle som sysler med placenta, enten i klinisk sammenheng og/eller i forskningssammenheng. For alle forskere som jobber med placenta, uansett stadium i forskerkarrieren, vil dette være en perfekt opplærings- og oppslagsbok. For medisinstudenter er den for nisjepreget i forhold til vanlige pensumkrav. Forfatterne presenterer oppdatert klinisk kunnskap og forskningsinformasjon på en integrert måte.

Det finnes flere lærebøker om placenta. Den klassiske læreboken av anatomene Peter Kaufmann og Kurt Benirschke har søkelyset rettet mot placentamorfologi og er mer rettet mot anatomer og patologer enn basalforskere og klinikere innen perinatalmedisinen (1). De tre redaktørene av denne nye placentaboken har legebakgrunn innen fødselshjelp og kvinnesykdommer, noe som synliggjøres ved mange gode og oppdaterte kliniske kapitler.

Hele 75 forfattere har bidratt til de 43 kapitlene. Det er seks deler, og det hele starter med en kort introduksjon til placentas sentrale rolle for fremtidig helse for mor og avkom. Del 2 er en god gjennomgang av dagens kunnskap om placentautvikling, -immunologi og fysiologi. Kompliserte temaer, slik som imprinting, forklares på en forståelig måte. Del 3 omhandler kliniske undersøkelser av placenta, med temaer som chordocentese, amniocentese, ultralydundersøkelse og dopplerstudier. Den fjerde delen inneholder enkle og gode sammendrag av forskjellige laboratoriemetodikker, inkludert trofoblastisolering og -celledyrkning, perfusjonsteknikker av placenta, proteomikk og isotopteknikker etc. Den femte delen omhandler placentas rolle ved forskjellige medisinske tilstander og svangerskapskomplikasjoner, slik som preeklampsi, diabetes, vekstrestriksjon, trombofilier, infeksjoner, aneuploide/polyploide placenta, trofoblastsvulster, abruptio placentae samt tvillingsvangerskap. Den siste delen peker mot fremtiden med temaer som navlesnorsblod til stamcelletransplantasjon og sirkulerende føtalt DNA og RNA innen prenatal diagnostikk (og preeklampsiprediksjon).

Kapitlene har en felles oppbygging med tre typer oppsummeringsfelter for å hjelpe leseren til å få med seg hovedpoengene. I Kliniske perler peker forfatterne på viktige temaer for klinisk praksis, mens de i Forskningshøydepunkter fremhever hovedpunkter for placentaforståelse. I korte oppsummeringer, merket Laringspoeng, forklarer de grunnleggende kunnskap til den uerfarne leseren.

Dette pedagogiske oppsettet, samt fine bilder og illustrasjoner, bidrar til at den vide målgruppen av lesere nås og at vanskelig stoff kan forstås. Flere av kapitlene har forslag til utfyllende lesning, inkludert nettressurser.

Kjøp, les og bli oppdatert!

\section{Annetine Staff}

Kvinne- og barneklinikken

Oslo universitetssykehus

og

Universitetet i Oslo

\section{Litteratur}

. Benirschke K, Kaufmann P, Baergen R. Pathology of the human placenta. 5. utg. New York, NY: Springer, 2006

\section{Noe å lære av Kaiser Permanente?}

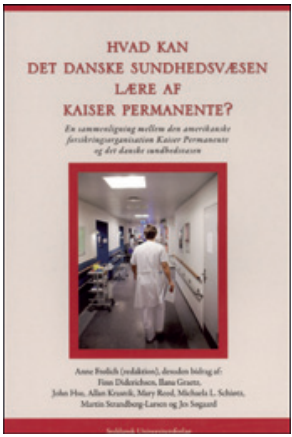

Anne Frølich, red.

Hvad kan det danske sundhedsvæsen lære av Kaiser Permanente?

En sammenligning mellem den amerikanske forsikringsorganisasjonen Kaiser Permanente og det danske sundhedsvæsen. 134 s, tab, ill. Odense M: Syddansk Universitetsforlag, 2011. Pris DKK 148

ISBN 978-87-7674-568-4

Danske og amerikanske forskere har sammenliknet det danske helsevesenet med det private amerikanske helsesystemet Kaiser Permanente (KP). Kaiser Permanente er et forsikringsfinansiert helsesystem som ble etablert i 1945, og som i dag forsikrer om lag ni millioner personer i ni stater i USA. Forskningsprosjektets mål var å identifisere organisatoriske faktorer som har betydning for kvaliteten på helsetjenestene for personer med kroniske sykdommer. Prosjektet har resultert i en rekke vitenskapelige artikler, og hovedresultatene presenteres i denne boken.

Forskerne har tatt i betraktning kostnader, kvalitet, liggedøgn i sykehus, antall helsearbeidere, sosioøkonomiske og helsemessige karakteristika ved befolkningen. I ett av de 11 kapitlene diskuterer forfatterne metodologiske utfordringer, og de konkluderer med at forutsetningene for de to helsesystemene er ganske ulike. Medlemmene i Kaiser Permanente er noe yngre enn befolkningen i Danmark, men har større forekomst av risikofaktorer og kronisk sykdom. Den danske ansvarsfordelingen mellom ulike forvaltningsnivåer representerer en vesentlig strukturell forskjell. Kostnadsnivået i den amerikanske helsesektoren påvirker på sin side kostnadsnivået i Kaiser Permanente.

Forskerne fant at Kaiser Permanente gjennomgående skåret høyere på kvalitet, men var kostnadsmessig noe dyrere enn det danske systemet. Kaiser Permanente hadde langt færre leger (43\%) og sykepleiere (56\%) per befolkningsenhet enn i Danmark. I Danmark var det $200 \%$ høyere forbruk av liggedøgn i sykehus enn i Kaiser Permanente. Samarbeidet mellom leger i og utenfor sykehus er langt tettere i Kaiser Permanente enn i Danmark, og det er lagt mer vekt på forebygging, standardisering og en helhetlig oppfølging av kronisk sykdom enn i Danmark.

Kaiser Permanente har etablert en rekke flerfaglige medisinske sentre utenfor sykehus, hvor allmennleger, spesialister og andre yrkesgrupper jobber sammen. Hele systemet nyter godt av at primærog spesialisthelsetjenesten har et felles journalsystem (HealthConnect). I Kaiser Permanente er det lagt stor vekt på integrasjon, klinisk ledelse, kvalitetsmonitorering og kvalitetsforbedring. Hva er det å lære? Forskerne peker bl.a. på at man i Danmark bør styrke helsetjenesten utenfor sykehus, med økt vektlegging av egenomsorg og bedre oppfølging av kronisk syke med sikte på å forebygge sykehusinnleggelser. Videre bør man bedre overvåkningen av kvaliteten i tjenestene, og man bør etablere felles IT-systemer som gjør det mulig å bruke virksomhets- og kvalitetsdata til å forbedre tjenestene.

Boken er lett å lese, og forfatterne har evnet å fremstille et komplisert materiale på en enkel måte. Selv om det er forskjeller mellom helsevesenet i Norge og Danmark, inneholder boken kunnskap og analyser som er relevante for diskusjonen om samhandlingsreformen og andre helseutfordringer vi står overfor i Norge.

Jan C. Frich

Avdeling for helseledelse og helseøkonomi Universitetet i Oslo 